Walisongo: Jurnal Penelitian Sosial Keagamaan

Vol. 28 No. 2 (2020) pp. $125-144$

DOI: $10.21580 /$ ws.28.2.6293

\title{
The Implementation of Ijtihād Jamā'iy in MUI's Fatwa Commission
}

\author{
Moh. Bahrudin,, ${ }^{*}$ Tulus Suryanto, ${ }^{2}$ Mohd Mizan bin \\ Mohammad Aslam ${ }^{3}$ \\ 1,2 Universitas Islam Negeri Raden Intan, Lampung, Indonesia; \\ ${ }^{3}$ Naif Arab University for Security Sciences (NAUSS), Riyadh, Saudi Arabia
}

\section{Abstract}

The Holy Quran and Sunnah contain universal values that require correct reasoning to be understood and applied by the Muslims. In this context, the scholars have been justified by Allah Almighty to undertake the $i j t i h \bar{a} d$ and $i j m \bar{a}$. This study aims to describe the $i j t i h \bar{a} d$ jamā'iy (collective ijtihād theory), as well as to analyze the implementation of ijtihād jamā'iy at MUI's Fatwa Commission in Lampung. This study is a combination of literature and field research. The data were obtained through literature studies of books, articles, and journals in related issues. Besides, the authors also interviewed MUI members to gain deeper information. Theoretically, the contemporary ijm $\bar{a}$ ' process can be pursued by an independent forum to conduct studies until a consensus is obtained from the majority of the participants. The panel must involve all religious elements in a representative manner. The practice of establishing Islamic law carried out by MUI's Fatwa Commission of Lampung Province is in accordance with the concept of ijtihād jamā'iy in the science of usūl fiqh. This analysis is important so that people have a high level of compliance after knowing that the MUI Lampung fatwa is ijma, which in fact is one of the sources of Islamic law.

Al-Qur'an dan Sunnah mengandung nilai-nilai universal yang membutubkan penalaran yang benar untuk dipahami dan dilaksanakan oleh umat Islam. Dalam konteks ini, para ulama telah diperkenankan

*Corresponding Author: Moh. Bahrudin (moh.bahrudin@radenintan.ac.id), Jl. Letnan Kolonel H. Endro Suratmin, Sukarame, Bandar Lampung, Indonesia 35131.

ISSN 0852-7172 (p) 2461-064X (e)

(C) 2020 by the Authors, published by Walisongo: Jurnal Penelitian Sosial Keagamaan https://journal.walisongo.ac.id/index.php/walisongo 
oleh Allah untuk melakukan ijtihād dan ïmä'. Penelitian ini bertujuan untuk mendeskripsikan teori ijtihād jamā'iy/ijtihād kolektif, serta menganalisis implementasi ijtihād jamā'iy di Komisi Fatwa MUI Lampung. Penelitian ini merupakan gabungan dari studi literatur dan penelitian lapangan. Data diperoleh melalui studi literatur pada buku, artikel, dan jurnal pada isu-isu terkait. Selain itu penulis juga mewawancarai anggota MUI untuk mendapatkan informasi yang lebih dalam. Secara teoritis, proses ijmā' kontemporer dapat ditempub melalui forum independen untuk melakukan kajian hingga diperoleh mufakat dari mayoritas peserta. Sidang harus melibatkan semua elemen agama secara representatif. Praktik penetapan hukum Islam yang dilakukan oleh Komisi Fatwa MUI Provinsi Lampung ini sesuai dengan konsep ijtihād jamā'iy dalam ilmu uṣūl fiqh. Analisis ini penting dilakukan agar masyarakat memiliki tingkat kepatuhan yang tinggi, setelah mengetahui bahwa fatwa MUI Lampung adalab ijma yang notabene merupakan salah satu sumber hukum Islam.

Keywords: fatwa; $i j t i h \bar{a} d j a m \bar{a} ' i y$; MUI

\section{Introduction}

One of the aspects in the science of $u s ̦ \bar{u} l$ al-fiqh that have significance and urgency to study is $i j m \bar{a}$. This is because $i j m \bar{a}$ ' has a critical and strategic position in Islamic law development. Ijm $\bar{a}$ ' is one of the law sources after the Quran and Sunnah, while the fourth source is Qiyas. The juridical-sociological consequence is that every problem that has been justified and legitimized by one of these sources of law has morally binding power and must be obeyed by Muslims. According to the science of uṣul fiqh, ijmā' is defined as the consensus of Muslim mujtahids at a time after the Prophet Mohammad died, over a sharia law related to human actions (Zahrah, 1978).

The Holy Quran and Sunnah have universal norms and spiritual values that serve as a way of life for people to achieve true happiness, as the Prophet Muhammad (pbuh) said, which guarantees that his people will not get lost if they follow the orders of Quran and Sunnah of the Prophet (al-Suyutii, 2012). Furthermore, Allah and Sunnah's book, which have the spirit of revelation, require correct interpretation and understanding by Muslims. In the early days of Islam, with the guidance 
of revelations (QS. al-Najm [53]:3-4), people immediately asked the Prophet if they faced legal problems. In the historical record of Islamic jurisprudence, this period is known as the laying foundation and establishing the law (Mahmassani, 1981). However, after the Prophet's death, the tashri' period had ended, and Muslims faced problems when there was a new legal case whose source was not found in the Quran or the Sunnah text. In this case, the scholars are justified to carry out ijtihād to determine and or enact Islamic law (Habib, 2006). Therefore, ijtihād is in a critical position in guarding the existence and continuity of Islamic law.

From the perspective of $u s \underline{u} l$ al-figh, ijtihäd means exerting all power and efforts to find laws from their source or apply them in the realm of life (Syathibi, 1976). Ijtihād can also be interpreted as serious work in providing correct legal solutions. The provisions in the Quran and Hadith's text can guide people according to situations and conditions (alBajiqani, 1968; al-Mahalli, 2001). Thus, it can be said that the correct interpretation and implementation of the word of Allah would be equivalent to the dynamics of $i j t i h \bar{a} d$ itself.

After Islamic rule expanded beyond the Arabian Peninsula, which had various cultures and patterns of social life that were different from Arabs, such as Syria, Egypt, Iran, and Rome (Syalabi, 1983). New problems arose when Scholars could not find legal status directly from the contents of the Quran or Hadith. In order to solve such problems, the Companions of Prophet are required to perform ijtihād. To protect the correctness of thought, the companions carry out intense dialogue and discussion so that the products of the friends' views are a collective consensus (Nasution, 2015).

When the jurisprudence of Islamic law contained in several major ușūlfiqh books by classical jurists was codified, science and technology's progress was not as advanced as it is today, and the problems faced by Muslims at that time were not as complex. In addition, collective $i j t i h \bar{a} d$ is needed so that existing problems can be viewed from various scientific 
disciplines (Nasution, 2015). According to Nasution (2015), what is needed is not global collective ijtiha $\bar{d}$, but a national or local one, because only those with good understanding and authorization of Islamic laws are allowed to perform ijtihād for the country.

There are several studies that examine ijtihād jamä'iy. Aznan Hasan (2003) had analyzed the concept of ijtihäd jamā'iy to determine new judicial decisions. He examines the theoretical framework of this kind of ijtih $\bar{a} d$ and its application by discussing the various institutions that practice it. Aznan presents a practical mechanism to ascertain the opinion of sharia about Muslims on various current issues.

Furthermore, Nasrullah (2017) examined the implementation of qiyas methodology as an effort to establish Islamic Law in Indonesia. The results of his research illustrated that from the historical dynamics of the application of the qiyas methodology, it can be seen that the patterns of such methodology of legal reasoning is applied in socio-religious organizations in Indonesia, including the MUI. However, there are weaknesses in its application, which happens because there is no attempt to update the methodology, which results in the reckless use of the methods produced by classical thinkers.

La Jamaa (2018) study found that the MUI's fatwas used dynamic methodologies in responding to the problems of Islamic law in general and contemporary Islamic law in Indonesia. In practice, the MUI's fatwas are not only based on Quran and Hadith, but they also use other arguments proportionally, either ijmā' and qiyās and istihsan, mașlahah mursalah, sadd al-dhari'ah and maqāsid al-shari'ah, or opinions of mu'tabar ulama. The MUI's fatwas have positive contributions to the transformation of contemporary Islamic law, both related to social, cultural, food, medicine, science, and technology areas, as well as worship, and the decisions of MUI regarding masāill diniyyah asasiyyah, wațaniyyah, masāil waqi'iyyah mu'asirah, masä'il qanuniyyah. During 1975 until 2011, the MUI produced 137 fatwas, either in the area of theology and religious sects (14 fatwas), the area of worship (37 fatwas), social and cultural area 
(51 fatwas), the area of food, medicine, knowledge, and technology (35 fatwas), and 50 decisions of MUI's Fatwa Commission in 2003, 2006 and 2009. Thus, for 26 years the MUI produced 137 fatwas and 50 decisions. This contributes positively to the development of contemporary Islamic law in Indonesia. Moreover, MUI is among the elements in contemporary Islamic law in Indonesia. Even the MUI's fatwas affect the development of national law.

Heri Fadli Wahyudi and Fajar (2018) conducted a study on the ijtihād methods of MUI's Fatwa Commission. The results of his research explained that the ijtihād methods used by MUI, in determining its fatwas, includes three approaches: first, the nas qat'iy approach, which used by the MUI in issuing fatwas limited to expose the arguments from the verses of the Quran and the Hadith of the Prophet with out explaining the guidance (dilalah) on the meaning of the problem being studied. Second, the qawliy approach in determining the fatwa, as the MUI does not only quote the opinions of the four imams of the madhhab, but also quotes the opinions of the four imams of the madhhab and their followers such as the imamiyah and dzahiriyah schools. Third, the manhajiy approach, which is applied only if the nas qat'iy and qawliy methods cannot provide a satisfactory answer to the problem under study.

By looking at some of the previous studies, it can be argued that Azman Hasan researched ijtihād jamā'iy by MUI, but did not explain how the format and mechanism of ijtihād jamā'iy in today's modern era. Meanwhile, Faishal Agil Munawar's study only explains that ijtihād jamä'iy is important to be implemented but does not discuss its application. Moreover, Nashrullah only stated how important it is to revive $i j t i h \bar{a} d$ and offered the qiyas as an alternative method and does not discuss ijtihād jamā'iy. Furthermore, La Jamaa only examines the contribution of MUI in responding the dynamics of Islamic law, by issuing fatwas, but does not study how the fatwa mechanism is produced. Finally, Heri Fadli Wahyudi, only alludes to the three approaches used by MUI in establishing the law, namely: the nash qațiy, qawliy and manhajiy 
approaches. The manhaji approach needs to be elaborated and studied more deeply regarding theoretical aspects and applications. One of the manhaj in legal stipulation is about collective $i j t i h \bar{a} d$, which is known as ijtihād jamā'iy.

This study of ijtihād jama'iy is the focus of this research, especially regarding its implementation in the Indonesian Ulama Council (Majelis Ulama Indonesia, MUI) of Fatwa Commission in Lampung Province, which has a significant role in the renewal and application of Islamic fiqh in Lampung Province. This is because the institution will be a place for community consultation regarding the implementation of Islamic law or contemporary jurisprudence. Therefore, the institution's accuracy and effectiveness in stipulating the law have to get various parties' attention, including from UIN Raden Intan Lampung.

By considering the above background, this research activity's focus includes two things: 1 ) What is the concept or theory of ijtihād jamā'iy which is rational and applicable in today's modern era? 2) Is the practice of establishing Islamic law carried out by MUI's Fatwa Commission in the Lampung Region in accordance with the theory of $i j t i h \bar{a} d$ jamá'i in $u s \underline{u} l$ al-fiqh?

Based on the formulation of the problem above, this research aims to describe the theory of $i j t i h \bar{a} d j a m \bar{a}$ 'iy or collective $i j t i h \bar{a} d$, which is rational and applicable in today's globalization era, when scientific discipline has developed rapidly. Ijtihād jamā'iy is expected to become an ijtihād method that can respond to science and technology developments today. This research also analyzed whether the stipulation of Islamic law (fiqh) carried out by the Fatwa Commission of MUI in Lampung is in line with normative principles and theory of $u s ̦ \bar{u} l$ al fiqh science. This analysis is essential so that people have a high level of compliance after knowing that the MUI Lampung fatwa is $i j m \bar{a}$, one of Islamic law sources, after the Quran and Sunnah.

The use of research implementation is that the theoretical aspects of $i j t i h \bar{a} d$ jam $\bar{a}$ iy obtained from literary sources or literature are expected to 
be used to implement collective ijtihād in today's modern era. This is because the existing ijtihād fardiy method may not be in accordance with modern science and technology dynamics. Besides, this research objective is also to document and present facts regarding the role of the Fatwa Commission of the Indonesian Ulama Council (MUI) in Lampung, how the council is answering and resolving contemporary legal problems chronologically, systematically and methodologically so that it can be accounted for scientifically. This study's results are also expected to be use das evaluation material for further research related to the appropriate ijtiha $\bar{d}$ method used in the modern era. Likewise, it is hoped that it will become concrete evidence that Islamic law has elasticity and flexibility.

This research's data collection methods were literature research and field studies. A literature study is a collection of data and information on various kinds of material stored in the literature, such as books, journals, or various other literary materials (Kartono, 1996). Interviews and observations did the field data collection. Interviews were conducted with the Lampung Province MUI Management. The data analysis method used was a qualitative data analysis. Qualitative data analysis is a research method that describes descriptive data sourced from respondents (Soekanto \& Mamudji, 2004). After the data were analyzed, the data were presented descriptively so that the real research result data depicted without adding or subtracting the data. Furthermore, the findings were drawn using the deductive thinking method, which relies on a general statement or hypothesis, then the premise is used to reach a specific, logical conclusion afterward (Hadi, 2015).

\section{Definition and Types of Ijtihād}

Ijtihād is a crucial and strategic method to guard the existence and continuity of Islamic legal rules when facing various legal problems. Etymologically, ijtihād comes from the word ijtahada-yajtahidu-ijtihādan (Yūnus, 2007), which means to be serious. Meanwhile, the terminological meaning of ijtiha $\bar{a}$ is to exert all power and efforts to find out the provisions of islamic law or to implement them (al-Shāțibiy, 1976). 
Ijtihād can be described as a serious effort to find the right legal provisions. The spiritual messages in the Quran and Hadith can guide people according to situations and conditions (al-Bajiqani, 1968; alMahalli, 2001). In other words, it can be seen that the study of divine revelation is good and benevolent.

From the perpetrator's side, ijtiha $\bar{d}$ is divided into two types, namely:

First, Ijtihād fardiy is the type of ijtihād carried out by a person or several people. There is no information that other mujtahids agreed to the result of the ijtihād. This type of ijtihād was signaled by the Prophet Muhammad to Mu'adz bin Jabal and ijtihād, which Umar bin Khattab emphasized to Abu Musa and Shuraih. Umar once stated to Shuraih: what is not real to you in the Sunnah, then do ijtihād to him using your mind (ash-Shiddieqy, 2001). Among the examples of $i j t i h \bar{a} d$ fardiy is Abu Bakr and Umar ibn Khattab's ijtihäd when determining the amount to be given to the Muhajirin and Ansar.

Second, ijtihād jamā'iy is the type of $i j t i h \bar{a} d$ against a problem that the other mujtahids then agreed upon (ash-Shiddieqy, 2001). This is the type of ijtihād in 'Ali ibn Abi Taalib's hadith when he has directly questioned the Prophet about a problem that was not found in the law in the Quran or the Sunnah. Then the Prophet Muhammad said: Gather together to determine the matter of knowledgeable people among those who believe and consult among you and do not leave it to one person's opinion.

\section{Legal Basis of Ijtihād}

A mujtahid in implementing ijtihäd must not rely solely on logical thought, but must be based on Islamic Law arguments. Among them is Allah's word whose essence is to instruct the faithful to always obey Allah, His Messenger and the $u l$ al-amri or the ruler, wherever we are (QS. al-Nisā' [4]: 59). According to scholars' interpretation, the word "al-amr" in QS. alNisā' [4] verse 59 is a synonym for "al-shay'in" which implies a case or field, covering both $u$ khrawiy and worldly affairs. In worldly affairs, those who are competent to regulate are the head of government, while in ukbrawiy or 
religious matters, those who have the right to regulate are the scholars. Thus, Muslims have an obligation to obey the scholars agreed consensus of an issue or law, which in ușūl fiqh is called $i j m \bar{a}$ (al-Zuhailī, 1986).

Regarding the proposition of $i j m \vec{a}$, from the hadith, the regulation refers to an incident experienced by Muadz bin Jabal when he was given a task by the Prophet Muhammad to become a judge in Yemen. When the Prophet (pbuh) sent Muadz to Yemen asking Muadz to do what would later be the basis for judging a case, Muadz said he would perform ijtihād based on the book of Allah, but if the evidence was not found in the Kitabullah, Muadz would use the Prophet's Sunnah. Finally, if there is no foundation in the Sunnah, Muadz would answer that he would perform ijtihād based on his own thoughts. Rasulullah Saw then said, "Praise be to Allah for giving guidance to the Messenger of the Prophet for something that was pleasing to Rasulullah"(al-Turmudhi, 1989; Bek, 1969).

According to most scholars, the above hadith presents the order configuration of the law source, which are the Quran, Sunnah, ijma, and qiyas. The Quran is the main legal proposition because it is the saying of Allah the Almighty, while the Sunnah is the second law source after the Quran as Sunnah is the explanation of the Prophet on the orders given to him. Meanwhile, the $i j m \bar{a}$ ' must be supported by the arguments of the Quran and/or Hadith. Qiyas can be used as a legal argument when qiyas has the support from Islamic Law as juridical reference Regarding qiyas, in order for it to be used as a legal argument, the islamic law must support it as a juridical reference (al-Rāziq, 1996; Schacht, 1971).

\section{Definition and Conditions of Mujtahid}

Based on the definition of $i j m \bar{a}$ ' stated earlier, it can be seen that the competence to act (abliyyat al-ijma') rests on the shoulders of the scholars. Imam Mahalli (2001) argues that scholars who are considered competent to perform ijtihād are experts in jurisprudence. Kitāb al-Ta'rîfāt by alJurjani (1983) explains that the mujtahid is people who have a deep understanding of the knowledge of the Quran and the science of interpretation since both are indispensable in exploring the meaning 
contained in the Quran. Al-Jurnani (1983) asserts that mujtahid must also master mushthalah hadith because using the knowledge mujtahid will be capable to describe the meaning in the hadith, and able to analogically reason, and also to be responsive to actual problems.

Taqiyuddīn Abū 'Ali al-Kāfi al-Subki (1984) explained the requirements for people who can perform ijtihād, they are: (a) having knowledge of tools (such as $u s \underline{u} l$ science, Arabic, manțīq science and others) to hone rationality and personality, to decrease the possibility of mistakes, able to pronounce appropriately, and to appropriately choose and sort out legal arguments; (b) understanding the theory and norms of ușull al-fiqh so they are able to use the arguments of Islamic Law correctly; (c) understanding maqāssid al-shari'ah and having capability to determine the law correctly, when the legal provisions are not stated sharia in the text of Islamic Law. The description above illustrates that a mujtahid in a broad sense is intellectual with intelligence and expertise in interpreting the law of the Quran and the hadiths of the Prophet to utilize them to find legal provisions for a new event that is not regulated explicitly (manțiuq) in the sharah text (al-Rāziq, 1996).

\section{Procedure and Mechanism of Ijtihād jamā'iy}

Epistemologically and philosophically, the theory of $i j m \bar{a}$ ' starts from the crystallization of Islam's basic teachings on shura so the people are consistent in acknowledging the infallibility of the consensus of the scholars (Hasan, 1994; Khalāf, 1978; Rahman, 1965). The ulama's consensus's infallibility is a form of glorification and respect for Allah to Muslims towards elasticity and flexibility of Islamic law. Ijmā' which is infallible and more objective can increase the quality of individual ijtihād product which could be an error (al-Zuhailīi, 1986).

Ijma $\bar{a}$ theory is designed to respond to practical needs and accommodate Muslims' opinions. Ijm $\bar{a}$ ' is a product of natural dialectics between the ulama and the people of his time. Ijm $\bar{a}$ ' is a form of prudence (ikhtiyat) and strengthens the understanding and implementation of Islamic law (al-Zuhailī, 1986). The ijmā' doctrine's substance and essence 
is the compilation of collective-collegial agreement democratically and independently regarding Islamic law.

According to the scholars of $u s \underline{u} l$ al-fiqh, there are four conditions for consent, which are: 1) there must be a number of mujtahid scholars, because an opinion from a single mujtahid cannot be called as an agreement; 2) the opinions that appear must be global and total, because if it is local and discontent exists, it means there is no agreement; 3 ) no one opposes the opinion, because opposition indicates that no agreement has been reached; 4) all mujtahids must be known to express their opinions clearly, not secretly (sukuti) (Khalāf, 1978; al-Sibri, 1975; al-Zuhailīi, 1986). Nonetheless, all the requirements of the $i j m \bar{a}$ ' boil down to the substance and essence of the $i j m \bar{a}$ : obtaining a collective-collegial agreement democratically and independently.

Competent scholars who can become the part of the $i j m \bar{a}$ ' must meet the following requirements: mastering Arabic; knowing the science of tafsir and muștalah al-hadìth; familiar with the fiqh material that has been agreed by the number of scholars or which is still in dispute; adept to ușūl fiqh so that it does not slip into mistakes when using law; knowing maquassid al-sharīah, that the purpose of establishing and implementing Islamic law is to bring benefit to all nature (al-Zuhailīi, 1986).

A question then arises: Are the requirements of a mujtahid mentioned in detail met by an Islamic scholar today, including in Lampung Province? In this regard, there are scholars who are of the view that fulfilling the requirements of the mujtahid will be difficult after the period of the figures of the priests of the madhhab. However, it needs to be pointed out that these strict conditions are actually an expression of the prudence of the ulama and are arranged when ijtiha $\bar{d}$ activities are relatively liberal without limits and are reinforced again by the emergence of a generation of scholars who echo the closed door of $i j t i h \bar{a} d$.

Regarding these conditions, Abu Zahrah (1978). Explained that these requirements apply to mujtahids absolutely, while the requirements are not required for mujtahid muntasib or mujtahid fi al-madhhab. In fact, 
according to Ali Abd al-Rāziq (1996), the description of the mujtahid criteria put forward by the scholars narrowed to qualified scholars who were able to carry out scientific studies in order to use fiqh law from the Quran and / or Hadith on new problems which is not mentioned explicitly (manthuq) in the scriptural text. Even according to the Hanabilah scholars, people who have such criteria will definitely appear in every generation (Khalāf, 1978; Zahrah, 1978; al-Zuhailī, 1986).

During the time of companions of Prophet Mohammad, ijm $\bar{a}$ ' flowed naturally as there was no standard pattern, process or procedure. According to historical records, not all jurists were invited by the Caliph or were present to discuss a legal issue during the time of companions. The Caliph invited scholars who were available to decide on law without having to wait for the scholars who were out of town. Not all jurists were involved in the process of conscience occurred during a companions' time (al-Khafif, 1989).

\section{Discussion and Analysis}

The Central MUI has issued regulations on procedures, mechanisms, and systems to determine fatwas or provide answers to religious issues. The guideline's urgency is also to prevent, or at least to minimize, differences in religious answers regarding the same issues issued by the Central MUI and Regional MUI, or between one Regional MUI and another Regional MUI. The regulation is transcribed in the Guidelines for Determining the Fatwa of the Central Indonesian Ulema Council Number: U-596 / MUI / X / 1997 (Bunyana, Chair of Fatwa Commision of MUI Lampung 2010-2015).

The guidelines for determining the fatwa mentioned above are always used by MUI's Fatwa Commission of Lampung Province when determining or answering religious issues that require a fatwa. Of course, every Fatwa must be based on the arguments of the Book of Allah (Quran) and the Sunnah, and not be against the benefit of the people. If the evidence is not found in the Quran or Hadith, then the fatwa must not 
contradict $i j m \bar{a}$, qiyās which are $m u$ 'tabar, and other legal arguments, such as istihsān, mașlahah mursalah, and sadd al-dhari'ah. In this case, MUI's Fatwa Commission's fatwa decision must refer to the opinions of the previous madhhab leader scholars, both those relating to legal arguments that have the same opinion in the studied issues or relating to the opposing arguments. Likewise, with experts' opinions in the field of issues for which a fatwa decision will be made, the Fatwa Commission must refer to and consider their opinion before giving a fatwa decision.

If the legal clarity in the study has been found, whether seen from the aspects of the arguments that refer to the texts of the Quran and Sunnah as well as from the opinions of the Imams of the madhhab, then in this case the Fatwa Commission will convey to those concerned regarding the cancellation and dismissal of the problems to be denied. Whereas in the case of difference among the schools of thought, what is stated is the result of tarjī by referring to and paying attention to figh muqāran (comparison) by using muqaran fil principles $u s ̦ \bar{u} l$ related to tarjīh.

Meanwhile, on issues that do not have a clear legal status, the Fatwa Commission will carry out an in-depth and comprehensive discussion and pay attention to the opinions and views developed during the Commission's session. After finding an agreement by presenting the Quran and the Sunnah's arguments and the views of the imams of the madhhab, the Fatwa Commission will establish a Final Fatwa Decree. Fatwa decisions will then be enacted by being signed by the Council's leaders in the form of a Fatwa Decree (SKF). The Fatwa Decree (SKF) must be formulated in such a way by using language that is easily understood by the wider community. The Fatwa Decree (SKF) contains the arguments for the decision accompanied by a brief description and analysis, including the source of the decision, as well as the follow-up formulation and recommendations and/or solutions needed as a consequence of the SKF.

At the Commission Meeting, the Chairperson of the Commission obtains input and considerations from a team of Commission members, 
determines the priority scale of issues to be discussed in the Commission meeting and sets a time schedule for the discussion. In this case, the Chairperson of the Commission can mandate or appoint one or more members of the Commission to prepare an academic paper on the issues to be discussed at the Commission Meeting, complete with arguments and arguments regarding the issues to be discussed at the Commission Meeting. The Chairperson of the Commission may also appoint a person or more to give an invitation to a Commission meeting, convey the main issues to be discussed. The manuscript must be received by Commission members and other meeting participants no later than three days before the day the Commission Meeting is held.

At the Fatwa Commission hearing, Bunyana (2019) explained that the commission session would be held if there was a request or question from the government, social community organizations, the general public, or from the MUI itself which according to the MUI Leadership Council was deemed necessary to discuss and issue a fatwa. The Fatwa discussion session is held chaired by the Chairperson of the Commission or his Deputy with the approval of the Chairperson of the Commission, attended by Commission members whose number is at least half of the participants invited to the meeting or if deemed necessary have met the quorum by the attendees or are deemed sufficient by the Chair of the Commission, and if deemed necessary, the Fatwa Commission will present experts with regard to the substance to be discussed to see the expert's opinion.

MUI's Fatwa Commission must carry out the procedures determined by the Central MUI in producing Fatwa Decrees because the Fatwa Decrees must be obtained based on an agreement by looking at the various opinions of scholars' madhhab, both scholars who agree with them and scholars who have different opinions. The aim is to avoid disagreements between the Central MUI and the Regional MUI on the same problem, because the Fatwa Decrees within the Central MUI and Regional MUI are equal positions and do not cancel each other out. Suppose there is a difference between the Central MUI Fatwa Decree and the Regional MUI Fatwa 
Decree regarding the same problem. In that case, a meeting is held between the two Leadership Councils to find the best solution.

As an institution that accommodates scholars to guide society, MUI is only tasked with assisting the government in carrying out matters relating to the benefit of the people such as issuing fatwa on matters of religion. Therefore, MUI only has the authority to issue fatwa related to general religious issues and concern Indonesian Muslims nationally at the central and regional level by first holding consultation with MUI / MUI's Fatwa Commission.

The Lampung Province MUI's Fatwa Commission's working mechanism is by forming a Special Team to carefully select the problems submitted by the community to the Fatwa Commission. According to the results of interviews with Bunyana, Sholihin, and Suhaili, it was found that there was a standard mechanism that served as a working guide for the Fatwa Commission of the Lampung Province MUI, starting from the Commission Meeting stage to obtaining a Fatwa Decree.

The Fatwa Commission hearing's decision is formulated into an MUI Fatwa Decree by the drafting team, which is then signed by the Chairperson and Secretary of the Commission. After being signed, the Fatwa Decree is reported to the MUI Leadership Council/Secretariat to then be issued in the form of an MUI Fatwa Decree, numbered and signed by the General Chairperson, General Secretary, and the Chairperson of MUI's Fatwa Commission. Fatwa decrees are published through the Mimbar Ulama journal. The explanation is in the form of articles, which are then submitted to the stakeholders concerned and all members of the Fatwa Commission and the Regency/City MUI.

\section{Conclusion}

Ijtihād is an activity of scholars to introduce and explore the materials and legal objectives (maquassid al-sharíah) in the Quran and or the Sunnah. Because the Quran and Sunnah contain universal values and ethical norms, it requires interpretation and internalization by the people to be 
implemented in life. This means that the most fundamental problem for Muslims is how to interpret and internalize the Quran and Sunnah.

The scholars received justification from Allah to perform ijtihād, either individually (fardiy) or collectively (jamā'iy). Collective ijtihād output is $i j m \bar{a}$. The essence contained in the $i j m \bar{a}$ ' is obtaining a collective-collegial agreement of the ulama in a democratic manner. The procedure, mechanism, and stages of ijtihād jamä'iy must be designed so that the substance and essence of the $i j m \bar{a}$ ' theory can be realized. Based on this line of thought, the ijtihād jamā'iy mechanism can be pursued by: Establishing an independent council to conduct studies until a consensus is obtained from the majority of participants; The study must involve all the clerical elements in a representative manner; and in certain cases, the assembly may summon experts in certain disciplines (specialists).

The implementation of ijtihād at MUI's Fatwa Commission in Lampung is led by the Chairman of the Commission or his Deputy. Meeting participants consist of commission members and other participants as deemed necessary. The meeting must be attended by half of the participants invited to the meeting or have met the attendees' quorum. The mechanism for determining the fatwa by MUI's Fatwa Commission in Lampung, namely that on issue which has clear laws, the Commission conveys existing provisions in accordance with the texts of the Quran and Sunnah. If there is different argument between madhhab, principles of fiqh muqāranah supposition is ultilized to result in tarjīh.

In practice, the Commission conducts a comprehensive discussion and takes into account the opinions of the session participants and then establishes a joint Fatwa Decree. Every Fatwa Decree must be enacted after being signed by the Leadership Council in the form of a Fatwa Decree. The Fatwa Commission meeting results are formulated by the Formulating Team into a Fatwa Decree signed by the Chairperson and Secretary of the Commission. The Fatwa decision is reported to the MUI Leadership Council/Secretariat to be enacted in the form of an MUI Fatwa Decree, complete with a number and signed by the General Chairperson, 
General Secretary and Chair of MUI's Fatwa Commission, and submitted to all Commission members and related parties.

Based on the explanation above, it can be concluded that the practice of determining Islamic law carried out by MUI's Fatwa Commission of Lampung Province is in accordance with the theory or concept of $i j t i h \bar{a} d$ jamā'iy in the science of $u s ̦ \bar{u} l$ figh. The disclosure of such conclusions is very important so that people have a high level of compliance after knowing that the MUI Lampung fatwa product is $i j m \bar{a}$, one of the sources of Islamic law, after the Quran Sunnah.

Lastly, the author will provide recommendations to Islamic religious assemblies, religious institutions, and religious mass organizations, including the state and government, to utilize the spirit of ijtihād jamā'iy as a social institution (social engineering) in managing social life affairs, especially in religious matters that are connected with the interests of the people. Ijtih $\bar{a} d j a m \bar{a}$ 'iy is an $i j t i h \bar{a} d$ system that is more realistic and ideal than $i j t i h \bar{a} d$ fardiy or individual $i j t i h \bar{a} d$, given the rapid development of scientific discipline, so that the expertise of various ijtihād members will complement each other. The completeness of Islamic law experts in ijtihād jamā'iy will certainly have implications for $i j t i h \bar{a} d$ products' fullness.[w]

\section{References}

al-Bajiqani, M. A. G. (1968). al-Madkhal ilā Ușūl al-Fiqh al-Mālikī. Beirut: Dār al-Libnan.

Bek, M. K. (1969). Ușūl al-Fiqh. Cairo: Maktabah al-Tijāriyah al-Kubrā.

Habib, S. A. (2006). Ensiklopedi Ijmak (S. Machfudz (trans.)). Jakarta: Pustaka Firdaus.

Hadi, S. (2015). Metodologi Riset. Yogyakarta: Pustaka Pelajar.

Hasan, A. (1994). Pintu Ijtihad sebelum Tertutup. Bandung: Pustaka.

Jamaa, L. (2018). Fatwas of the Indonesian Council of Ulama and Its Contributions to the Development of Contemporary Islamic Law in Indonesia. Indonesian Journal of Islam and Muslim Societies, 8(1), 29-56. https://doi.org/10.18326/ijims.v8i1.29-56 
al-Jurjani, Ali bin Muhammad bin 'Ali al-Zayn al-Sharîf. (1983). Kitāb Al-Ta'rîfät. Beirut: Dār al-Kutub al-'Ilmiyyah.

Kartono, K. (1996). Pengantar Metodologi Riset Sosial. Bandung: Mandar Maju.

al-Khafïf, A. (1989). Asbāb al-Ikbtilāf fī al-Fiqh. Cairo: Dār al-Kutub al'Ilmiyyah.

Khalāf, A. W. (1978). 'Ilm Ușūl al-Fiqh. Cairo: Dār al-Qalam.

al-Mahalli, J. (2001). Sharh Jāmi' al-Jawāmi. Beirut: Dār Ihyā' al-Kutub al-'Arabiyyah.

Mahmassani, S. (1981). Filsafat Hukum dalam Islam (A. Sudjono (trans.)). Bandung: Al-Maarif.

Nasrullah, N. (2017). Majelis Ulama Indonesia (MUI); Studi Atas Penggunaan Metodologi Qiyas sebagai Upaya Penetapan Hukum Islam di Indonesia. Al-Fikra: Jurnal Ilmiab Keislaman, 16(2), 332. https://doi.org/10.24014/af.v16i2.4026

Nasution, H. (2015). Islam: Ditinjau dari Berbagai Aspeknya. Jakarta: UI Press.

Rahman, F. (1965). Islamic Metodology in History. Karachi: Central Institute of Islamic Research.

al-Rāziq, A. A. (1996). al-Ijmā' fi al-Sharīah al-Islāmiyyah. Mesir: Dār alFikr al-'Arabiy.

Schacht, J. (1971). The Origins of Muhammadan Jurisprudence. London: Oxford at the Clarendon Press.

al-Shātibiy, A. I. S. I. M. L. G. A. I. (1976). al-Muwāafaqāt. Cairo: Muștafā al-Bābi al-Halabi.

ash-Shiddieqy, T. M. H. (2001). Pengantar Hukum Islam. Semarang: Pustaka Rizki Putra.

al-Sibri, Z. (1975). Maṣādir al-Aḥkām al-Islāmiyyah. Cairo: Dār al-Itihād al-'Arabiy.

Soekanto, S., \& Mamudji, S. (2004). Penelitian Hukum Normatif Suatu Tinjanan Singkat. Jakarta: Raja Grafindo Persada.

al-Subki, T. A. Al. K. (1984). al-Ibhaj fi Ușūl al-Minhājo. Beirut: Dār alKutub al-'Ilmiyyah.

al-Suyuți, J. D. (2012). al-Jāmi’ al-Ṣāghir. Beirut: Dār al-Kitab al-'Ilmiyah. 
Syalabi, A. (1983). Sejarah dan Kebudayaan Islam (M. Yahya (trans.)). Jakarta: Pustaka Al-Husna.

al-Turmudhi. (1989). al-Jāmi’ al-Sậ̄ḥ Sunan al-Turmudhi. Beirut: Dār Ihyā'.

Wahyudi, H. F., \& Fajar, F. (2018). Metode Ijtihad Komisi Fatwa Majelis Ulama Indonesia dan Aplikasinya dalam Fatwa. Cakrawala: Jurnal Studi Islam, 13(2), 120-133. https://doi.org/10.31603/cakrawala. v13i2.2402

Yūnus, M. (2007). Kamus Arab-Indonesia. Jakarta: Hidakarya Agung.

Zahrah, M. A. (1978). Ușūl al-Fiqh. Mesir: Dār al-Fikr al-'Arabiy.

al-Zuhailī, W. (1986). Ușūl al-Fiqh al-Islāmī (1st ed.). Beirut: Dār al-Fikr. 
The page was intentionally left blank. 